Jurnal Pemberdayaan: Publikasi Hasil Pengabdian kepada Masyarakat

Vol. 2, No. 1, April 2018, Hal. 165-170

ISSN: 2088 4559; e-ISSN: XXXX-XXXX

DOI:

\title{
PELATIHAN PEMBUATAN KRIPIK DAUN KERSEN MASYARAKAT BALIREJO, MUJA-MUJU, UMBULHARJO, YOGYAKARTA
}

\author{
Caraka Putra Bhakti, Nuim Hidayat \\ Universitas Ahmad Dahlan, Yogyakarta \\ Email: caraka.pb@bk.uad.ac.id
}

\begin{abstract}
ABSTRAK
Salah satu masalah di Kelurahan Muja-Muju yaitu masih banyaknya ibu rumah tangga yang hanya mengurus rumah tangga saja yaitu sebanyak 1.402 jiwa serta warga yang belum memiliki pekerjaan sebanyak 325 jiwa. Maka KKN Alternatif 61 UAD mengadakan program LABU KRIDASEN (Pelatihan Pembuatan Kripik Daun Kersen). Metode pelaksaan yang dilakukan meliputi: (1) Pendidikan Masyarakat dengan penyuluhan mengenai khasiat daun kersen serta makanan dan minuman olahan daun kersen, (2) Praktek langsung dengan melakukan pelatihan pembuatan kripik kersen. Program ini bertujuan untuk mengurangi pengangguran dan memanfaatkan waktu luang ibu-ibu Muja-muju, khususnya warga RW 6 Balerejo. Hal tersebut diharapkan dapat menciptakan masyarakat yang kreatif dan produktif. Metode pelaksanaan yang digunakan adalah pelatihan. Hasil pelatihan menunjukkan peserta mendapatkan pengetahuan manfaat daun karsen dan keterampilan dalam pembuatan kripik daun kersen.
\end{abstract}

Kata kunci: pelatihan,keripik, daun kersen, Balerejo, Mujamuju

\begin{abstract}
One of the problems in Muja-Muju Sub-District is that there are still many housewives who only take care of the household, which are 1,402 people and 325 people who don't have jobs. Then Alternative KKN 61 Unit III.C.1 UAD runs the KRIDASEN LABU program (Kersen Leaf Chips Making Training). The implementation methods include: (1) Community Education with counseling on the efficacy of kersen leaves and processed foods and drinks of kersen leaves, (2) Direct practice by conducting training in making kersen chips. This program aims to reduce unemployment and take advantage of the free time of the Muja-muju mothers, especially residents of $R W$ 6 Balerejo. So as to create a creative and productive society. The implementation method used is training. The training results showed participants gained knowledge and skills in making kersen leaf chips.
\end{abstract}

Keywords: training, chips, kersen leaves,Balerejo, Mujamuju 


\section{PENDAHULUAN}

Kersen atau talok adalah nama sejenis pohon yang buahnya kecil dan manis. Nama ilmiah pohon ini adalah Muntinga calabura. Kersen merupakan tanaman buah tropis yang mudah dijumpai di pinggir jalan. Kersen biasanya ditemui dengan ukuran kecil, pohonnya selalu hijau terus menerus, berbunga dan berbuah sepanjang tahun (Binawati dan Amilah, 2013).Tanaman kersen ini termasuk jenis tanaman dikotil, secara mikroskopis struktur anatomi daun kersen muda dan tua terdiri dari epidermis atas dan epidermis bawah, trikoma, mesofil (parenkim palisade/tiang dan parenkim spons/bunga karang), jaringan penguat (kolenkim), kristal, jaringan pembuluh (xilem dan floem) (Kuntorini dkk, 2013).

Hasil penelitian uji fitokimia (Arum dkk, 2012), pada daun kersen terdapat adanya flavonoid, triterpenoid, alkaloid, saponin, dan steroid. Berdasarkan uji fitokimia yang telah dilakukan tersebut menandakan adanya flavonoid mampu menghambat aktivitas bakteri, sehingga daun kersen kaya akan manfaat untuk dikonsumsi. Selama ini daun karsen hanya dikonsumsi dengan direbus saja, padahal daun karsen ini dapat diolah menjadi berbagai macam makanan dan minuman yang dapat meningkatkan nilai ekonomi daun kersen, sehingga hal ini dapat menjadi peluang bisnis, misalnya dengan dibuat kripik.

Kelurahan Muja Muju memiliki 12 RW dan 55 RT. Di RW 6 Balirejo terdapat 4 RT yaitu RT 18, 19, 20, dan 53. Berdasarkan statistik penduduk DIY, mayoritas pekerjaan masyarakat Muja Muju adalah karyawan swasta yaitu sebanyak 2.273 dan wiraswasta sebanyak 1.177, sedangkan yang mengurus rumah tangga sebanyak 1.402, sebagai pelajar/ mahasiswa 1.921, dan yang belum bekerja sebanyak 325 jiwa (Statistik Penduduk DIY, 2018)

Dari uraian di atas, diharapkan dengan adanya penyuluhan mengenai khasiat daun kersen dan dengan adanya pelatihan pembuatan kripik daun kersen dari mahasiswa KKN Bersama dosen pembimbing lapangan, ibu rumah tangga dan masyarakat yang belum bekerja dapat membuka usaha kripik kersen sehingga menjadi masyarakat kreatif dan produktif.

\section{METODE}

Untuk mencapai tujuan yang diharapkan, maka program kerja mahasiswa KKN di RW 6 Balerejo Kelurahan Muja-Muju difokuskan pada pemberdayaan masyarakat dengan 
metode pendidikan masyarakat dan praktek secara langsung. Ringkasan metode pelaksanaan beserta Jam Kerja Efektif Mahasiswa (JKEM) tersedia pada table 1.

Tabel 1. Metode, Kegiatan, dan JKEM

\begin{tabular}{rrr}
\hline No $\quad$ Metode & \multicolumn{1}{c}{ Kegiatan } & \multicolumn{1}{c}{ JKEM } \\
\hline 1 Penyuluhan & $\begin{array}{l}\text { Menyelenggarakan penyuluhan } \\
\text { mengenai manfaat/ khasiat daun }\end{array}$ & 3 X 50 menit \\
& $\begin{array}{l}\text { kersen } \\
\text { Menyelenggarakan penyuluhan } \\
\end{array}$ & 3 X 50 menit \\
& $\begin{array}{l}\text { mengenai berbagai } \\
\text { makanan/minuman olahan daun } \\
\text { kersen }\end{array}$ \\
& $\begin{array}{l}\text { Pelatihan membuat kripik daun } \\
\text { kersen }\end{array}$ & 3 X 100 menit \\
\hline Jumlah JKEM & & 600 menit \\
\hline
\end{tabular}

\section{HASIL, PEMBAHASAN, DAN DAMPAK}

Program KKN ingin memanfaatkan khasiat daun kersen sekaligus mengembangkan jiwa kewirausahaan warga RW 6 Balirejo, Kelurahan Muja-Muju, maka diperlukan penyuluhan mengenai khasiat dan macam-macam makanan/minuman olahan daun kersen, serta pelatihan pembuatan makanan olahan daun kersen, berupa kripik daun kersen.

Kegiatan ini bertujuan untuk memberi pengetahuan mengenai kandungan yang ada dalam daun kersen, seperti: flavonoid, triterpenoid, alkaloid, saponin, dan steroid. Berdasarkan uji fitokimia yang telah dilakukan oleh Arum dkk. (2012), menandakan adanya flavonoid mampu menghambat aktivitas bakteri. Khasiat yang terkandung pada daun kersen menurut Florido dkk (1991), tanaman kersen diduga sebagai antispasmodik.

Daun kersen dapat menurunkan kadar gula bagi penderita diabetes karena mengandung saponin dan flavonoid. Daun ini juga dapat mengantisipasi kolesterol, asam urat, hipertensi, kanker, flu, batuk, peradangan dan lain sebagainya (Cintai Hidup, 2017). Menurut Meiliza dan Hariyatmi (2013), daun kersen mempunyai banyak khasiat diantaranya sebagai antiseptik, anti inflamasi, antitumor, dan antiasam urat. Sifat antiimflamasi (anti peradangan) pada daun kersen dapat menghambat terjadinya peradangan di daerah-daerah sendi sehingga mengurangi nyeri pada penderita (Noorhamdani, Yosef, dan Rosalia, 2014). 
Daun biasanya dikonsumsi dengan cara direbus, diseduh atau dibuat teh, karena lebih memaksimalkan khasiat dari daun kersen tersebut. Namun, untuk menarik konsumen, daun kersen dapat diolah menjadi berbagai macam makanan, contohnya kripik daun kersen.Tidak hanya daun kersen saja yang dapat diolah menjadi makanan, buah kersen juga dapat diolah menjadi berbagai makanan, yaitu: sirup, puding, selai, dan dodol kersen (Laswati dkk, 2017).

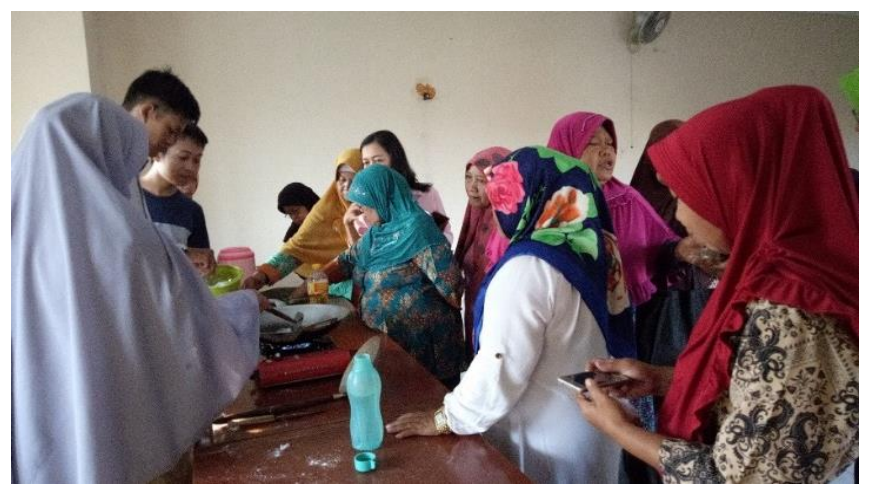

Gambar 1. Antusiasme ibu-ibu Balerejo mengikuti pelatihan kripik Kersen

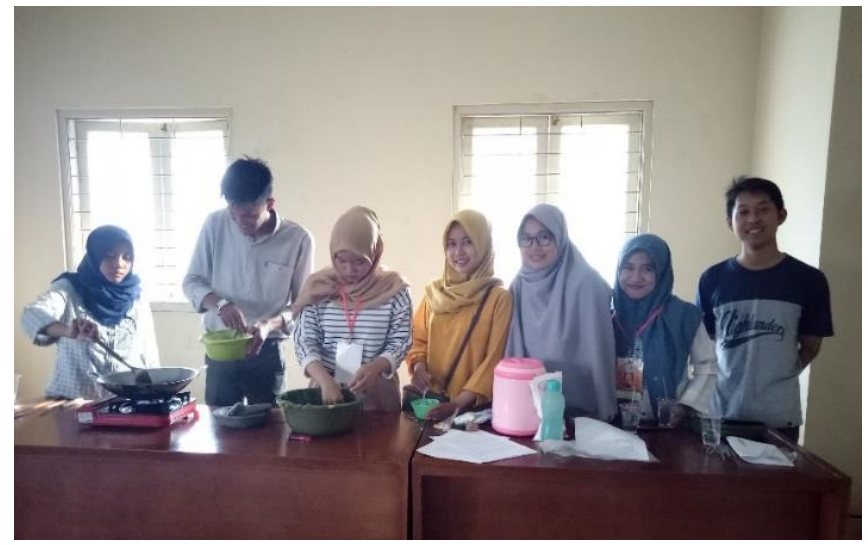

Gambar 2. Mahasiswa KKN sedang melakukan LABU KRIDASEN

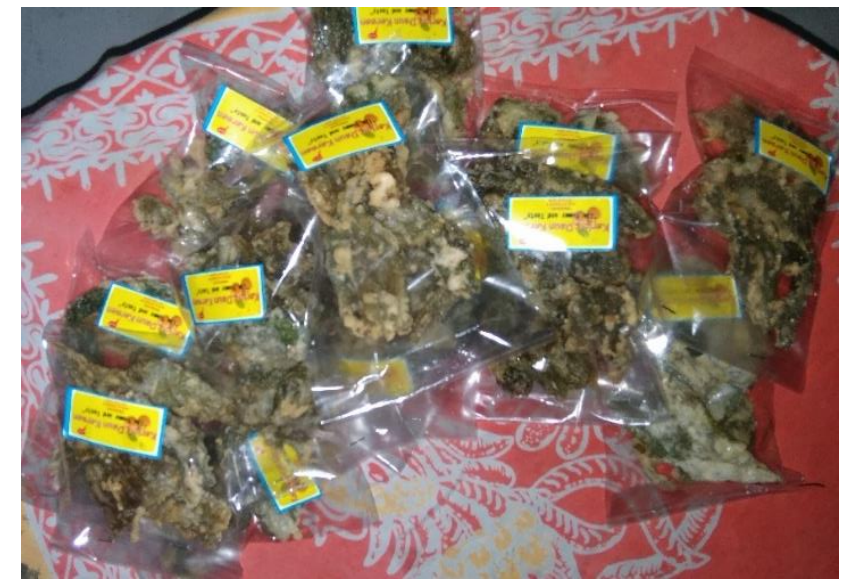

Gambar 3. Produk kripik daun kersen 
Hasil pelatihan menunjukkan peserta pelatihan dapat menghasilkan produk berupa keripik kersen. Pemanfaatan daun kersen untuk olahan pangan sudah banyak dilakukan, antara lain, sebagai permen jelly (Huda dkk, 2015), minuman teh ( Lathief, 2016), kripik, selai, dan teh seduh (Laswati dkk, 2017). Dengan demikian daun kersen telah terbukti aman dikonsumsi masyarakat.

Diharapkan kegiatan ini dapat bermanfaat dan dapat menjadikan peluang usaha bagi warga Balirejo RW 6. Selanjutnya, dapat menjadikan masyarakat yang produktif dan kreatif serta peluang usaha ini dapat memperkecil angka pengangguran di daerah tersebut.

\section{SIMPULAN}

Program KKN UAD Bersama DPL telah memberdayakan masyarakat Muja-Muju khususnya RW 6 Balirejo dengan memberikan pengetahuan mengenai kandungan dan khasiat daun kersen serta memberikan pelatihan bagaimana cara mengolahnya menjadi kripik kersen yang renyah dan enak. Kegiatan ini diharapkan dapat membuka peluang usaha sehingga dapat menciptakan masyarakat yang produktif dan kreatif sehingga memperkecil angka pengangguran di daerah tersebut.

\section{DAFTAR PUSTAKA}

Arum, YP. Supartono dan Sudarmin. 2012. "Isolasi dan Uji Daya Antimikroba Ekstrak Daun Kersen (Muntingia calabura)". Jurnal MIPA 35 (2): 165-174.

Binawati, D. K., dan Amilah, S. 2013. "Effect of Cherry Leaf (Muntingia calabura L.) Bioinsecticides Extract Towards Mortality of Worm Soil (Agrotis ipsilon) and Armyworm (Spodoptera exiqua) on Plant Leek (Allium fistolum)". Wahana, 61(2):5157.

Cintai Hidup. (2015, 17 Juni). Rahasia 15 manfaat daun kersen untuk kesehatan dan kecantikan. Diperoleh 19 Desember 2018, dari_http://cintaihidup.com/rahasia-15manfaat-daun-kersen-untuk-kesehatan-dan-kecantikan/

Florido, H.B., Saplan, J.C., Arcilla, R.P., Cadiz, R.T., Modino., R.C., and Almario, S.C., 1991, Research Information Series Ecosystem.

Huda, S., Syahputra, Anggono, dan Wahyuni. 2015. Pemanfaatan Daun Kersen(Muntingia calabura) sebagai Permen Jelly terhadap Daya Terima Konsumen. Teknologi Pangan Vol. 6 No. 1

Kuntorini, Evi Mintowati. Setya Fitriana dan Maria Dewi Astuti. 2013. "Struktur Anatomi dan Uji Aktivitas Antioksidan Ekstrak Metanol Daun Kersen (Muntingia calabura)". Prosiding Semirata. Lampung: FMIPA Universitas Lampung.

Laswati, D. T., Natalia R. I. S., dan Anggraini, Oktavia. 2017. Pemanfaatan Kersen (Muntingia calabura L.) sebagai Alternatif Produk Olahan Pangan: Sifat Kimia dan Sensoris. Yogyakarta: Universitas Widya Mataram. 
Lathief, Y. 2016. Skripsi :Pengaruh Lama Fermentasi Daun Kersen terhadap Total Asam, pH, dan Aktivitas Daun Kersen. Malang: UIN Maulana Malik Ibrahim.

Meiliza , E.R., dan Hariyatmi. 2013. Pengaruh Jus Buah Kersen terhadap KadarAsam Urat Darah Mencit (Mus musculus). Surakarta: Program Studi Biologi, FKIP

Noorhamdani, Yosef, dan Rosalia. 2014. Uji Ekstrak Daun Kersen (Muntingia calabura) sebagai Antibakteri terhadap Methicillin-Resistant Staphylococcus aureus (MRSA) secara in Vitro. Malang: Laboratorium Fakultas Kedokteran. Universitas Brawijaya. 